\title{
THE CHALLENGE OF ASEAN MIGRANT WORKERS' WELFARE COMMODITAZION VERSUS HUMAN RIGHTS?
}

\author{
V.L. Sinta Herindrasti \\ Lecturer, International Relations Study Program \\ Universitas Kristen Indonesia Jakarta \\ Email: Valentina.herindrasti@uki.ac.id
}

\begin{abstract}
Abstrak
Perhatian kritis terhadap fenomena pekerja migran dan permasalahannya pada tingkat regional semakin menguat seiring dengan universalisasi prinsip Hak Asasi Manusia (HAM). Tidak terkecuali di Asia Tenggara, dimana tingkat migrasi pekerja dari satu negara anggota ASEAN ke negara lain menunjukkan kecenderungan yang semakin meningkat. Timbulnya masalah pelecehan, eksploitasi bahkan kekerasan yang menimbulkan kematian para pekerja migran di negara tujuan menunjukkan bahwa terdapat masalah "ancaman kemanusiaan" yang sangat mendasar di balik struktur sosial, ekonomi, politik dan hukum yang sebenarnya tidak ramah terhadap eksistensi pekerja migran. Inisiatif ke arah perlindungan hukum oleh regim internasional telah dilaksanakan melalui berbagai konvensi internasional, khususnya Konvensi Internasional tentang Perlindungan Hak-Hak Seluruh Pekerja Migran dan Anggota Keluarganya (1990); namun pada tingkat ASEAN mengemukanya kepentingan masing-masing negara justru menjadi penghalang ratifikasi bersama Instrumen Perlindungan Hak-Hak Buruh Migran di ASEAN. Mengapa sebagian negara anggota ASEAN menolak? Bagaimana peran ASEAN dalam inisiatif ini? Tulisan ini dimaksudkan untuk mempertanyakan sejauh mana kesediaan anggota ASEAN untuk melindungi pekerja migran sebagai test case atas pencapaian tujuan inti Masyarakat Sosial Budaya ASEAN 2025 yaitu komitmen untuk meningkatkan kualitas hidup rakyat melalui kerja sama yang berorientasi pada rakyat, berpusat pada rakyat. Penelitian ini menggunakan pendekatan kualitatif dengan metode deskriptif analitis dengan meneliti dan memahami makna dari data sekunder dan primer. Penulis berargumen bahwa kepentingan nasional dan "bargaining power" negara penerima merupakan penghalang perwujudan perjanjian perlindungan hak-hak pekerja migran dan keluarga di ASEAN. Negara inisiator seperti Indonesia dan Filipina harus terus mendorong anggota lain untuk menciptakan Perundangan Nasional dan menstandardisasikan Kebijakan Nasional pekerja migran menjadi satu Hukum Kebiasaan (Customary Law) melalui Perjanjian Regional. Sentralisasi akan menjamin bahwa perlindungan terhadap seluruh pekerja migran dapat ditanggung melalui praktek berbagi resiko oleh seluruh anggota ASEAN.
\end{abstract}

Kata kunci: ASEAN, Hak Asasi Manusia, Pekerja Migran, Perjanjian Regional

\begin{abstract}
Critical attention toward migrant worker issues in the regional level grows in accordance with the universalization of human rights principle. There is no exception in Southeast Asia, where the level of interstate labour migration shows an increasing trend. Cases of exploitation and violence on migrant workers in recipient countries clearly indicate the existence of basic "humanity threat", which intimidate migrant workers, on social, economic and political structures.
\end{abstract}


Legal protection initiatives have been conducted by international regimes, especially through the Convention on the Protection of the Rights of all Migrant Workers and Members of their Families (1990). However, in ASEAN level, strong interests from each state member has caused difficulties in the ratification of the ASEAN Instrument of the Protection of the Rights of Migrant Workers. Why do most ASEAN countries refuse to ratify the instrument? What is the role of ASEAN in this initiative? This paper examines how far ASEAN countries will protect their workers, which further test their commitment on ASEAN Social Cultural Community 2025's goal of increasing the quality of people's life through peoplecentred and people-oriented cooperation. This paper applies qualitative approach with descriptive analysis method by exploring and understanding the meaning of primary and secondary data. This paper further argues that national interests of recipient countries are the main factor in preventing the ratification of the Instrument of the Protection of the Rights of Migrant Workers in ASEAN. Initiator nations like Indonesia and the Philippines must keep trying to approach other ASEAN state members to encourage creating National Law and standardizing the National Policy for migrant workers as one centralized Customary Law through the Regional Agreement. Centralization will ensure that protection to all migrant workers can be shouldered through risk-sharing practice by all ASEAN state members.

Keywords: ASEAN, Human Rights, Migrant Workers, Regional Agreement.

\section{Introduction}

Increasing interconnection between countries on South East Asia region due to globalization has caused various "crossborder" issues among ASEAN state members. One of the most significant issues is related to migrant workers. The issue is unavoidable since in the dynamics of global economies where workers experience interstate, regional (out-of-state within one region) and global (out-of-state and out-of-region) mobilities, complex problems involving various state and nonstate parties will arise.

Various problems arising from migrant worker sector in ASEAN are mostly about discrimination, violence and exploitation, which are all considered as violations to Human Rights. These violations must be responded by ASEAN since ASEAN holds universal value that requires cooperative responsibilities from every ASEAN state member as part of the international society.

The principle of protection for migrant workers is written in the ASEAN Declaration on the Protection and Promotion of the Rights of Migrant Workers (asean.org), which was declared at the $12^{\text {th }}$ ASEAN Summit on 13 January 2007, in Cebu, Phillipines. The declaration contains commitments for every ASEAN state member as sender and recipient of migrant workers to work together in solving undocumented migrant worker 
issues and in respecting basic rights of migrant workers. As a follow-up to the commitments, ASEAN Committee on the Implementation of the ASEAN Declaration on the Protection and Promotion of the Rights of Migrant Workers (ACMW) was founded on 30 July 2007. ACMW is assigned to form ASEAN Instruments to be ready to be implemented.

In a decade, however, the process of creating and negotiating ASEAN Instrument on the Protection and Promotion of the Rights of Migrant Workers has yet to be fully agreed due to differences in negotiation positions between sender and recipient countries of migrant workers. Why this important and noble instrument meant to protect the rights of migrant workers in ASEAN experiences stagnation? In what way that sender and recipient countries fail to agree? As an initial study, this paper tries to dig fundamental reasonings of why the parties fail to agree on some part from the goal of forming ASEAN society, which is the Strengthening of Social Protection for Susceptible Migrant Workers (Ministry of Foreign Affairs, 130). This paper will analyze the case of two migrant worker recipient countries, Singapore and Malaysia, which are strategic and important for Indonesia.
The Development of the ASEAN Instrument on the Protection and Promotion of the Rights of Migrant Workers

ASEAN Declaration on the Protection and Promotion of the Rights of Migrant Workers states four main principles in regards to migrant worker protection, which are the following: (i) Both the receiving states and sending states shall strengthen the political, economic and social pillars of the ASEAN Community by promoting the full potential and dignity of migrant workers in a climate of freedom, equity, and stability in accordance with the laws, regulations, and policies of respective ASEAN Member Countries; (ii) The receiving states and the sending states shall, for humanitarian reasons, closely cooperate to resolve the cases of migrant workers who, through no fault of their own, have subsequently become undocumented; (iii) The receiving states and the sending states shall take into account the fundamental rights and dignity of migrant workers and family members already residing with them without undermining the application by the receiving states of their laws, regulations and policies; and (iv) Nothing in the present Declaration shall be interpreted as implying the regularisation of the situation 
of migrant workers who are undocumented. (Koesnanti, 2010:34).

In accordance with the Declaration, recipient states are responsible of the following:

(i) Intensify efforts to protect the fundamental human rights, promote the welfare and

uphold human dignity of migrant workers; (ii) Work towards the achievement of harmony and tolerance between receiving states and migrant workers; (iii) Facilitate access to resources and remedies through information, training and education, access to justice, and social welfare services as appropriate and in accordance with the legislation of the receiving state, provided that they fulfil the requirements under applicable laws, regulations and policies of the said state, bilateral agreements and multilateral treaties; (iv) Promote fair and appropriate employment protection, payment of wages, and adequate access to decent working and living conditions for migrant workers; (v) Provide migrant workers, who may be victims of discrimination, abuse, exploitation, violence, with adequate access to the legal and judicial system of the receiving states; and (vi) Facilitate the exercise of consular functions to consular or diplomatic authorities of states of origin when a migrant worker is arrested or committed to prison or custody or detained in any other manner, under the laws and regulations of the receiving state and in accordance with the Vienna Convention on Consular Relations.

Meanwhile, sending countries are responsible of the following: (i) Enhance measures related to the promotion and protection of the rights of migrant workers; (ii) Ensure access to employment and livelihood opportunities for their citizens as sustainable alternatives to migration of workers; (iii) Set up policies and procedures to facilitate aspects of migration of workers, including recruitment, preparation for deployment overseas and protection of the migrant workers when abroad as well as repatriation and reintegration to the countries of origin; and (iv) Establish and promote legal practices to regulate recruitment of migrant workers and adopt mechanisms to eliminate recruitment malpractices through legal and valid contracts, regulation and accreditation of recruitment agencies and employers, and blacklisting of negligent/unlawful agencies (Koesnanti, 2010: 36-37).

To further explain the principles of the Declaration, ASEAN Committee on Migrant Workers (ACMW) was formed in Singapore on 2008. ACMW acts as a focal point for ASEAN in terms of coordinating 
the implementation of the Declaration and facilitating improvements of protection instruments and migrant worker rights. ACMW adopts Term of Reference and and Work Plan that cover four main motivations, which are the following:

(i) step up protection and promotion of the rights of migrant workers against exploitation and mistreatment; strengthen protection and promotion of the rights of migrant workers by enhancing labour migration governance in ASEAN member states; (iii) Regional cooperation to fight human trafficking in ASEAN in collaboration with the Senior Officials Meeting on Transnational Crime; (iv) Development of an ASEAN Instrument on the Protection and Promotion of the rights of migrant workers (Document of ASEAN Committee).

The main agenda of ACMW is to compose the ASEAN Instrument on the Protection and Promotion of the Rights of Migrant Workers by forming the ACMW Drafting Team (ACMW-DT) in 2009. The member of ACMW-DT includes Indonesia, Philippines, Malaysia and Thailand. With the Instrument, ASEAN is hoped to have a strong law basis in handling protection and promotion of migrant worker rights that align with an ASEAN's vision, which is a caring and sharing community (MFA 2010: 226-227).
ACMW-DT has actively done several meetings. In 2009, ACMW's "Workshop on Scope Coverage for Migrant Workers and A Common Understanding on Rights of Migrant Workers" was held in Phillipines. In the same year, ACMW-DT meeting in Bangkok agreed on the Outline Instrument. ACMW-DT meeting in Bali produced Terms of Reference (ToR) that covered purpose, functions, membership, leadership, reporting mechanism, meeting schedule, financing and function of the ASEAN secretariat. Initial Instrument Draft, which is the "ASEAN Agreement on the Protection and Promotion of the Rights of Migrant Workers", is created by the Phillipines and Indonesia. The Draft contained 12 articles, which are:

Article 1: Coverage

Article 2: Definition of Terms

Article 3: Objectives

Article 4: Common Rights of Migrant Workers and Members of Their Families Article 5: Specific Rights of Regular Migrant Workers

Article 6: Common Obligations among Member States

Article 7: Obligations of Sending States Article 8: Obligations of Receiving States Article 9: Migrant Worker's Grievances Article 10: Dispute Settlement Mechanism Article 11: Application of the Agreement 
Article 12: General Provisions

Different stances exist between sending countries and recipient countries regarding definition, scope of migrant worker and family protection of right and nature of instrument.

During ACMW-DT meeting in Kuala Lumpur, Malaysia, differences in position paper occured between sending countries (Phillipines and Indonesia) and recipient countries (Malaysia, Singapore, Thailand, Brunei Darussalam). Sending countries wanted the Instrument to be legally binding, to include undocumented workers, and to include articles about respecting the rights of migrant worker's family members. Meanwhile, recipient countries wanted the Instrument to be not legally binding, to only include documented workers, to not include the rights of migrant worker's family members and to try to restrict the scope of migrant worker's rights. Outside of this two groups, Laos, Cambodia and Myanmar are flexible regarding the instrument.

Deadlock always prevailed until the $15^{\text {th }}$ meeting. During the ASEAN Labour Minister's Meeting (ALMM) in Davao City on 20 February 2017, the definition of "migrant worker" has been agreed by all parties, which is the following:
"Migrant worker" refers to a person who is to be engaged or employed, is engaged or employed, or has recently been engaged or employed in a remunerated activity in a State of which he or she is not a national. The applicability of (the instrument) to different categories of migrant workers shall be subject to the laws, regulations and policies of respective ASEAN Member States". (Working Draft, 2017:5).

Various stances from each ASEAN state member in regards to the discussion of the ASEAN Instrument on the Protection and Promotion of the Rights of Migrant Workers in 2016 are summarized in the table below. The first issue is whether the instrument should be legally binding or not. Recipient countries (Brunei Darussalam, Malaysia, Singapura, Thailand) reject the Instrument to be legally binding, whereas two sending countries (Indonesia, Phillipines) agree for the Instrument to be legally binding, two countries are flexible (Cambodia, Myanmar), and two countries reject (Vietnam, Laos).

The second issue is whether the Instrument will also protect undocumented migrants. Three recipient countries (Brunei Darussalam, Malaysia, Thailand) reject, including Myanmar. Three countries declare themselves flexible (Singapore, Phillipines, Laos). Lastly, three countries 
are in favour (Indonesia, Vietnam, Cambodia).

Regarding the third issue of protection of rights to migrant family members, three recipient countries reject (Brunei, Malaysia, Singapore), five countries are in favour (Thailand, Indonesia, Phillipines, Cambodia, Vietnam, Myanmar), and one country declare itselfs flexible (Laos).

Regarding the the scope of migrant worker right issues, four recipient countries (Brunei, Malaysia, Singapore, Thailand, Laos) try to restrict the scope, two countries (Indonesia, Cambodia) do not want to restrict the scope, and three countries (Phillipines, Vietnam, Myanmar) are absent from giving their opinions. Every state members agree to finalize the issues in September 2016 or in September 2017 ASEAN Summit at the latest.

If no agreement can be achieved between sending and recipient countries in 2017, then the ASEAN Instrument on the Protection and Promotion of the Rights of Migrant Workers cannot be applied. Various efforts by Indonesia on the past 10 years in terms of bilateral and multilateral negotiations as well as approaches to recipient countries have yet to result in unification of various ASEAN state member interests in one "common platform" for the protection of ASEAN migrant workers. 


\section{MANDALA}

Jurnal Hubungan Internasional

Vol.1No.2

Juli-Desember

2018

\begin{tabular}{|c|c|c|c|c|c|c|c|c|c|c|c|}
\hline & & \multicolumn{4}{|c|}{ Recipient Countries } & \multicolumn{6}{|c|}{ Sending Countries } \\
\hline $\begin{array}{l}\mathbf{N} \\
\mathbf{0}\end{array}$ & Issue & Brunei & Malaysia & $\begin{array}{c}\text { Singapor } \\
\mathrm{e}\end{array}$ & Thailand & Indonesia & $\begin{array}{c}\text { The } \\
\text { Philippines }\end{array}$ & Vietnam & $\begin{array}{c}\text { Cambodi } \\
\mathbf{a}\end{array}$ & Lao & $\begin{array}{c}\text { Myanma } \\
\mathbf{r}\end{array}$ \\
\hline 1 & Status & $\begin{array}{l}\text { Recipient } \\
\text { Country }\end{array}$ & $\begin{array}{l}\text { Recipient } \\
\text { Country }\end{array}$ & $\begin{array}{l}\text { Recipient } \\
\text { Country }\end{array}$ & $\begin{array}{l}\text { Recipient } \\
\text { Country }\end{array}$ & $\begin{array}{l}\text { Sending } \\
\text { Country }\end{array}$ & $\begin{array}{l}\text { Sending } \\
\text { Country }\end{array}$ & $\begin{array}{l}\text { Sending } \\
\text { Country }\end{array}$ & $\begin{array}{l}\text { Sending } \\
\text { Country }\end{array}$ & $\begin{array}{l}\text { Sending } \\
\text { Country }\end{array}$ & $\begin{array}{l}\text { Sending } \\
\text { Country }\end{array}$ \\
\hline 2 & $\begin{array}{l}\text { Legal Nature } \\
\text { of the } \\
\text { Instrument }\end{array}$ & $\begin{array}{l}\text { Non- } \\
\text { legally } \\
\text { binding. } \\
\text { Must be } \\
\text { based on } \\
\text { law and } \\
\text { regulation } \\
\text { in each } \\
\text { ASEAN's } \\
\text { member } \\
\text { country }\end{array}$ & $\begin{array}{l}\text { Non legally } \\
\text { binding }\end{array}$ & $\begin{array}{l}\text { Non- } \\
\text { legally } \\
\text { binding }\end{array}$ & $\begin{array}{l}\text { Non-legally } \\
\text { binding }\end{array}$ & $\begin{array}{l}\text { Legally } \\
\text { binding. } \\
\text { Provide } \\
\text { effective } \\
\text { protection as } \\
\text { ASEAN as } \\
\text { rule-based } \\
\text { community. }\end{array}$ & $\begin{array}{l}\text { Open to option } \\
\text { of legally } \\
\text { binding based } \\
\text { on } 4 \\
\text { parameters: } \\
\text { (1) Immediate } \\
\text { development of } \\
\text { an action plan } \\
\text { with time lines } \\
\text { to implement } \\
\text { the instrument; } \\
\text { (2) negotiation } \\
\text { of bilateral } \\
\text { labour } \\
\text { agreements } \\
\text { between AMS, } \\
\text { (3) Sharing and } \\
\text { documentation } \\
\text { of best } \\
\text { practices; (4) } \\
\text { designation of } \\
\text { national focal } \\
\text { points on } \\
\text { instrument } \\
\text { implementatio } \\
\text { n. }\end{array}$ & $\begin{array}{l}\text { Welcomed a } \\
\text { non-legally } \\
\text { binding } \\
\text { instrument } \\
\text { towards a } \\
\text { legally- } \\
\text { binding } \\
\text { instrument in } \\
\text { the future } \\
\text { with a clear } \\
\text { phased } \\
\text { approach. }\end{array}$ & Flexible & $\begin{array}{l}\text { Non- } \\
\text { legally } \\
\text { binding }\end{array}$ & Flexible \\
\hline 3 & $\begin{array}{l}\text { Protection of } \\
\text { the rights of } \\
\text { undocumente } \\
\text { d migrant } \\
\text { workers }\end{array}$ & $\begin{array}{l}\text { Do not } \\
\text { provide } \\
\text { protection }\end{array}$ & Refuse & Flexible & $\begin{array}{l}\text { Firmly state } \\
\text { do not } \\
\text { provide } \\
\text { protection } \\
\text { toward rights } \\
\text { of }\end{array}$ & $\begin{array}{l}\text { Do not } \\
\text { deferentiate } \\
\text { between } \\
\text { documented } \\
\text { and } \\
\text { undocumente }\end{array}$ & Flexible & $\begin{array}{l}\text { Support } \\
\text { protection } \\
\text { towards } \\
\text { rights of } \\
\text { undocumente } \\
\text { d migrant }\end{array}$ & $\begin{array}{l}\text { Support } \\
\text { based on } \\
\text { Cebu } \\
\text { Declaration }\end{array}$ & Flexible & $\begin{array}{l}\text { Not } \\
\text { support }\end{array}$ \\
\hline
\end{tabular}




\section{MANDALA}

Jurnal Hubungan Internasional

Vol.1No.2

Juli-Desember

2018

\begin{tabular}{|c|c|c|c|c|c|c|c|c|c|c|c|}
\hline & & & & & $\begin{array}{l}\text { undocumente } \\
\text { d migrant } \\
\text { workers. }\end{array}$ & $\mathrm{d}$ & & workers. & & & \\
\hline 4 & $\begin{array}{l}\text { Protection of } \\
\text { fundamental } \\
\text { rights and } \\
\text { dignity of } \\
\text { family } \\
\text { members }\end{array}$ & Refuse & Refuse & Refuse & $\begin{array}{l}\text { Support } \\
\text { rights of } \\
\text { migrant } \\
\text { workers' } \\
\text { family. }\end{array}$ & $\begin{array}{l}\text { Instrument } \\
\text { should } \\
\text { respect rights } \\
\text { of family } \\
\text { members; at } \\
\text { least family } \\
\text { members who } \\
\text { stay together } \\
\text { with the } \\
\text { migrant } \\
\text { worker. }\end{array}$ & $\begin{array}{l}\text { Instrument } \\
\text { should respect } \\
\text { rights of family } \\
\text { members; at } \\
\text { least family } \\
\text { members who } \\
\text { stay together } \\
\text { with the } \\
\text { migrant } \\
\text { worker. }\end{array}$ & $\begin{array}{l}\text { Instrument } \\
\text { should } \\
\text { respect rights } \\
\text { of family } \\
\text { members; at } \\
\text { least family } \\
\text { members who } \\
\text { stay together } \\
\text { with the } \\
\text { migrant } \\
\text { worker. }\end{array}$ & $\begin{array}{l}\text { Support } \\
\text { rights of } \\
\text { migrant } \\
\text { workers' } \\
\text { family. }\end{array}$ & Flexible & $\begin{array}{l}\text { Instrument } \\
\text { should } \\
\text { respect } \\
\text { rights of } \\
\text { family } \\
\text { members; } \\
\text { at least } \\
\text { family } \\
\text { members } \\
\text { who stay } \\
\text { together } \\
\text { with the } \\
\text { migrant } \\
\text { worker. }\end{array}$ \\
\hline 5 & $\begin{array}{l}\text { Scope of } \\
\text { Rights of } \\
\text { Migrant }\end{array}$ & $\begin{array}{l}\text { Try to } \\
\text { narrowin } \\
\mathrm{g} \text { the } \\
\text { scope of } \\
\text { migrant } \\
\text { worker's } \\
\text { rights } \\
\text { among } \\
\text { others by } \\
\text { giving } \\
\text { their } \\
\text { basic } \\
\text { rights } \\
\text { only in } \\
\text { the work } \\
\text { place. }\end{array}$ & $\begin{array}{l}\text { Trying to } \\
\text { narrow the } \\
\text { scope of } \\
\text { migrant } \\
\text { worker's } \\
\text { rights } \\
\text { among } \\
\text { other things } \\
\text { by giving } \\
\text { their basic } \\
\text { rights only } \\
\text { in the work } \\
\text { place. } \\
\text { Prohibit } \\
\text { doing } \\
\text { peaceful } \\
\text { assembly } \\
\text { and } \\
\text { narrowing } \\
\text { access to }\end{array}$ & $\begin{array}{l}\text { Trying to } \\
\text { narrow the } \\
\text { scope of } \\
\text { migrant } \\
\text { worker's } \\
\text { rights. } \\
\text { Only to the } \\
\text { migrant } \\
\text { worker } \\
\text { who has } \\
\text { job } \\
\text { relation, } \\
\text { and } \\
\text { prohibit } \\
\text { peaceful } \\
\text { assembly } \\
\text { and } \\
\text { narrowing } \\
\text { access to } \\
\text { justice. }\end{array}$ & $\begin{array}{l}\text { Trying to } \\
\text { narrow the } \\
\text { scope of } \\
\text { migrant } \\
\text { worker's } \\
\text { rights among } \\
\text { other things } \\
\text { by giving } \\
\text { their basic } \\
\text { rights only in } \\
\text { the work } \\
\text { place. }\end{array}$ & $\begin{array}{l}\text { Instrument } \\
\text { must cover } \\
\text { the whole } \\
\text { scope of } \\
\text { migrant } \\
\text { worker's } \\
\text { rights by } \\
\text { providing } \\
\text { protection of } \\
\text { basic rights in } \\
\text { the whole } \\
\text { area of } \\
\text { recipient } \\
\text { country. }\end{array}$ & - & - & $\begin{array}{l}\text { Trying not } \\
\text { to narrow } \\
\text { the scope } \\
\text { of migrant } \\
\text { worker's } \\
\text { rights. } \\
\text { Giving } \\
\text { basic rights } \\
\text { in the } \\
\text { whole area } \\
\text { of recipient } \\
\text { country. }\end{array}$ & $\begin{array}{l}\text { Refuse } \\
\text { the rights } \\
\text { of } \\
\text { migrant } \\
\text { worker } \\
\text { to } \\
\text { conduct } \\
\text { peaceful } \\
\text { assembly } \\
\text {. }\end{array}$ & - \\
\hline
\end{tabular}




\section{MANDALA}

Jurnal Hubungan Internasional

Vol.1No.2

Juli-Desember

2018

\begin{tabular}{|c|c|c|c|c|c|c|c|c|c|c|}
\hline & & & justice. & & & & & & & \\
\hline 6 & $\begin{array}{l}\text { Timeline } \\
\text { finalisation }\end{array}$ & $\begin{array}{l}\text { Agree } \\
\text { with } \\
\text { timeline } \\
\text { of } \\
\text { Septembe } \\
\text { r } 26^{\text {th }} \text {, } \\
2016 \text { or } \\
\text { April } \\
2017 \text { at } \\
\text { the latest. }\end{array}$ & $\begin{array}{l}\text { Support } \\
\text { finalization } \\
\text { on } 2017 \text { but } \\
\text { amendable } \\
\text { to open for } \\
\text { negotiation } \\
\text { up to } 2020 \text {. } \\
\text { Malaysia is } \\
\text { waiting for } \\
\text { on going } \\
\text { plan to joint } \\
\text { with TPP } \\
\text { legislative } \\
\text { review. } \\
\text { Result of } \\
\text { review can } \\
\text { change } \\
\text { Malaysian's } \\
\text { position in } \\
\text { the } \\
\text { negotiation } \\
\text { (refer to the } \\
\text { chairman } \\
\text { statement in } \\
\text { the } 26^{\text {th }} \\
\text { ASEAN } \\
\text { Conference } \\
\text { where } \\
\text { leader } \\
\text { giving task } \\
\text { to ALMM } \\
\text { to do } \\
\text { finalization) } \\
\text {. }\end{array}$ & $\begin{array}{l}\text { Agree with } \\
\text { timeline of } \\
\text { end of } \\
2016 \text { or } \\
\text { April } 2017 \\
\text { at the } \\
\text { latest. }\end{array}$ & $\begin{array}{l}\text { Agree with } \\
\text { timeline of } \\
\text { end of } 2016 \\
\text { or April } 2017 \\
\text { at the latest. }\end{array}$ & $\begin{array}{l}\text { Agree with } \\
\text { time line of } \\
\text { end of } 2016 \\
\text { or April } 2017 \\
\text { at the latest } \\
\text { (during } \\
\text { ASEAN } \\
\text { Conference). } \\
\text { If cannot be } \\
\text { finalized then } \\
\text { agree to raise } \\
\text { the issue in } \\
\text { the ASEAN } \\
\text { Conference } \\
\text { September } \\
\text { 2017. }\end{array}$ & $\begin{array}{l}\text { Agree with } \\
\text { time line } \\
\text { September } \\
2016 \text { or April } \\
2017 \text { at the } \\
\text { latest. } \\
\text { Propose that (i) } \\
\text { ACMW and } \\
\text { SLOM use the } \\
\text { result of } \\
\text { ASEAN } \\
\text { Convention } \\
\text { Against } \\
\text { Trafficking in } \\
\text { Persons } \\
\text { Especially } \\
\text { Women and } \\
\text { Children, } \\
\text { ASEAN } \\
\text { Declaration on } \\
\text { Strengthening } \\
\text { Social } \\
\text { Protection and } \\
\text { KL Declaration } \\
\text { on Irregular } \\
\text { Movement of } \\
\text { People in SEA } \\
\text { as source of } \\
\text { consideration } \\
\text { and (ii) to } \\
\text { consider a } \\
\text { progressive } \\
\text { realization of a } \\
\text { legally-binding } \\
\text { instrument } \\
\text { whereby the } \\
\text { ACMW and }\end{array}$ & $\begin{array}{l}\text { Support } \\
\text { finalization } \\
\text { of the } \\
\text { instrument } \\
\text { as soon as } \\
\text { possible. }\end{array}$ & $\begin{array}{l}\text { Agree with } \\
\text { timeline } \\
\text { September } \\
2016 \text { or } \\
\text { April } 2017 \\
\text { at the } \\
\text { latest. If } \\
\text { cannot be } \\
\text { finalized } \\
\text { agree to } \\
\text { ask } \\
\text { guidance to } \\
\text { AMM or } \\
\text { ASCC } \\
\text { (SOCA). }\end{array}$ & $\begin{array}{l}\text { Agree with } \\
\text { timeline } \\
\text { September } \\
2016 \text { or } \\
\text { April } 2017 \\
\text { at the } \\
\text { latest. }\end{array}$ \\
\hline
\end{tabular}




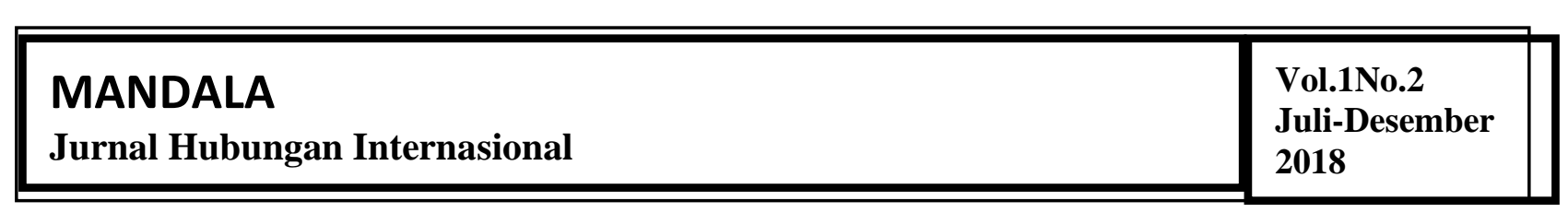

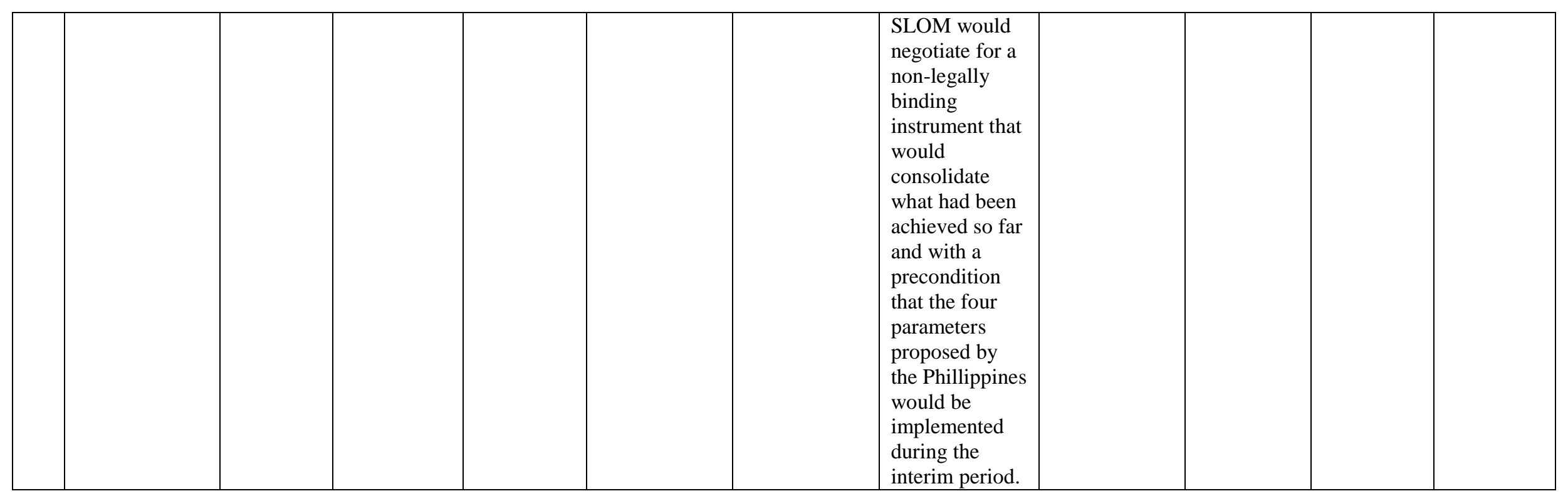

Source: Working Draft ASEAN Instrument on the Protection and Promotion of the Rights of Migrant Workers as of Year 2016. 
Indonesia's Urgency Regarding the Ratification of ASEAN Instrument on the Protection and Promotion of the Rights of Migrant Workers

As largest migrant worker sending country in ASEAN, Indonesia is highly concerned with the ratification of the ASEAN Instrument on the Protection and Promotion of the Rights of Migrant Workers, especially in the context of ASEAN Economic Community where the creation of a single market and production will be marked by the free flow of commodities, services, investments and skilled workers (MFA, 2010: 54). Shift in employment due to development in many fields surely open the possibility of mobilities for various types of workers in ASEAN countries to fill the vacancies left by domestic workers. ASEAN market's principle will bring together "supply and demand" of workers, including migrant workers.

So far, the sending of migrant workers has brought positive economic impacts in terms of opening employment, generating remittance (http://www.bnp2tki.go.id/read/11560/BN P2TK). that moves the nation's economy and reduces unemployment. In the other hand, various problems faced by migrant workers must also be anticipated considering that the problems are not solely considered as violations against criminal laws, but also considered as violations against Human Rights.(www.bnp2tki.go.id/uploads/data/d ata_10-08-2017_021223). From sending countries such as Indonesia, weaknesses, which are considered to be internal factors, in terms of Laws regarding migrant worker placement abroad, coordination between government agencies and various parties involved, as well as sending of unskilled migrant workers for informal sector, must be admitted. (https://sekartrisakti.wordpress.com/2011/ 10/04). Therefore, Indonesia's efforts in ratificating the ASEAN Instrument on the Protection and Promotion of the Rights of Migrant Workers are only parts of the entire improvement.

\section{Interests of Recipient Countries:}

\section{Singapore and Malaysia}

Each ASEAN state member has national interests that must be considered. The interests will serve unique positions which are not similar one to another. In every negotiation processes, meeting dynamic shows countries which are persistent and countries which are not. There exists at least three different stances regarding the articles in the Instrument draft, which are agreeing, rejecting or flexible. Four main factors that contribute to rejection against ratification by recipient 
countries and sending countries are (1) the nature of the Instrument, (2) acceptance of the migrant worker's family, (3) protection for documented and undocumented migrants, and (4) development or human right approaches.

\section{Singapore}

Singapore is one of the wealthiest country in the world in regards to strong international trade. Singapore has one of the busiest ports in the world in regards of commodities tonnages handled. Singapore also has similar amount of Gross Domestic Product (GDP) compared to developed nations in Western Europe. Its economy heavily depends on export, particularly on consumer electronics, information technology (IT) products, pharmacy and financial services. (http://www.bnp2tki.go.id/read/11943/SIN GAPURA.html).

In terms of employment, Singapore is one of the main destination for sending countries (Indonesia, Phillipines) in both formal and informal sectors. Data about placement of Indonesia workers as per June 2016 for formal sector is 65.137 workers, whereas for informal sector is 54.208 workers. In June 2017, the placement for formal sector reaches 57.272 workers, whereas the placement for informal sector reaches 44.005 workers.
Placement destination of Singapore per June 2016 is 8.324 people and per June 2017 is 6.522 people (http://www.bnp2tki.go.id/uploads/data/dat a_07-07-). For Indonesia, Singapore is the second destination country in ASEAN after Malaysia. With population of 5.535 million people as well as a direct neigbour to Indonesia, the economy relations between the nations becomes highly strategic. The amount of remittance from Singapore to Indonesia reaches $\mathrm{Rp}$ 99.962.824 (as per April 2016) and Rp 89.562.044 (as per April 2017). (http://www.bnp2tki.go.id/uploads/data/dat a_07-07-).

As a developed country, Singapore has its own regulations, which are the Employment of Foreign Manpower Act (EFMA) released by the Singapore Ministry of Manpower, regarding foreign domestic worker. (http://www.mom.gov.sg/legislation/emplo yment-of-foreign-manpower-act). EFMA regulates work contracts (specifically regulates wage, holidays in a week, credit, compensation, etc.), therefore it is slightly difficult for Singapore to follow the legally binding nature of the ASEAN Instrument. To ensure the continuity of sending and receiving migrant workers, Singapore also uses bilateral mechanism. For example, both Indonesia and Singapore has a 
memorandum, which is the Memorandum of Understanding Between The National Board of Placement and Protection of the Indonesian Overseas Workers and Association of Employment Agencies (Singapore) on the Placement and Protection of Indonesian Overseas Workers in Singapore, in February 2016 that specifically accommodates interests of both nations (Http://jdih.bnp2tki.go.id/images/mouln/). Regarding the right of migrant workers to join in a labour union or a labour association, the ASEAN Instrument will also "collide" with the freedom to unionize in Singapore. In this matter, Singapore has its own interest to protect its political and economic stability, including their domestic workers and entrepreneurs.

If the recognition of migrant worker family's right is agreed, then the national expenditure will be affected, especially to provide housing, education and other needs. On the other hand, the living space in Singapore is limited. Singapore assertively does not provide any protection to undocumented migrants considering the rules from the Employment of Foreign Manpower Act in which workers who enter Singapore must fulfil Work Permit conditions beforehand. Cases of undocumented migrants will go through already existing law procedures.
Even though Singapore accepts migrant workers, regulations have set clear rules regarding giving of information, training and returning to home country. Most of migrant workers in Singapore are considered white collar who have skills, therefore regulations under Employment Act and EFMA are clear. In terms of national security, criminality threats, distribution of illegal drugs and terrorism have been anticipated in strict worker and immigration regulations. Regarding human right approach in convention, if one looks closely on the Instrument's articles, in general the entire ASEAN state member agrees on the contents. However, each nation's political system will determines whether human right activism possible to be done by migrant workers considering Singapore ASEAN Migrant Workers' Working Task have accommodated civil society organizations and labour union representatives through consultation forum that provides feedbacks and recommendations to the Singapore government.

\section{Malaysia}

In ASEAN, Malaysia is considered a developed country with population of 30 million people. The population consisted of Malay $(50,1 \%)$, Chinese $(22,6 \%)$, native $(11,8 \%)$, other $(0,7 \%)$ and non-citizen $(8,2 \%)$. Malaysia's GDP per capita is US\$ 
25,100

(2014).

(http://www.bnp2tki.go.id/read/11405/MALAYSIA.html

) .

Malaysia is situated very close to Indonesia, Singapore, Brunei, South China Sea and Vietnam, which is very strategic for regional and international trades. Population with high income opens employment for semi-skilled sectors such as agriculture, construction and industrial.

Malaysia is a main destination for migrant workers coming from Indonesia. Placement of migrant workers reached 46.253 people as per June 2016 and 38.864 people as per June 2017 (http://www.bnp2tki.go.id/uploads/data/dat a_07-07-). On the other hand, Indonesia has received remittance of $\mathrm{Rp} 707.460 .011$ as per April 2017. (http://www.bnp2tki.go.id/uploads/data/dat a_07-07-). Like Singapore, Malaysia firmly rejects four main factors which become the difference of the state's position paper. Malaysia even stricts the scope of migrant worker's rights other than human rights, peaceful assembly and access to justice system. Malaysia's stance is related to its national agenda regarding integration of Trans Pacific Partnership (TPP).

The summary of rejection factors to the ASEAN Instrument on the Protection and Promotion of the Rights of Migrant Workers for recipient countries
(Singapore and Malaysia) can be examined in tables below:

\section{Singapore's Rejection Rationale to Issues in ASEAN Instrument on the Protection and Promotion of the Rights of Migrant Workers 2017}

\begin{tabular}{|c|c|c|}
\hline $\begin{array}{l}\mathrm{N} \\
\mathrm{O}\end{array}$ & Issue & Singapore \\
\hline 1 & $\begin{array}{l}\text { The } \\
\text { nature of } \\
\text { the } \\
\text { Instrume } \\
\text { nt } \\
\text { (legally } \\
\text { binding) }\end{array}$ & $\begin{array}{l}\text { Rejecting, because Singapore } \\
\text { has its own Labour/Foreign } \\
\text { Worker acts: } \\
\text { - Employment of Foreign } \\
\text { Manpower Act } 1990 \\
\text { (chapter 91A) regulates } \\
\text { about procedures for } \\
\text { foreign workers in } \\
\text { Singapore, Act (since } \\
\text { Immigration Aspect } \\
\text { 1919) regulates the aspect } \\
\text { of Singapore's } \\
\text { immigration, such as } \\
\text { procedures to enter and to } \\
\text { exit Singapore. } \\
\text { Employment Act of } \\
\text { Singapore - The main } \\
\text { Labour Act in Singapore } \\
\text { regulates basic terms and } \\
\text { conditions in workplace. } \\
\text { (http://www.mom.gov.sg/ } \\
\text { employment- } \\
\text { practices/employment- } \\
\text { act). Memorandum of } \\
\text { Understanding Between } \\
\text { the National Board of } \\
\text { Placement and Protection } \\
\text { of the Indonesian } \\
\text { Overseas Workers and } \\
\text { Association } \\
\text { Employment Agencies } \\
\text { (Singapore) on the } \\
\text { Placement and Protection } \\
\text { of Indonesian Overseas } \\
\text { Workers in Singapore, } \\
\text { Februari 2016. }\end{array}$ \\
\hline & & $\begin{array}{l}\text { Ratification means the state is } \\
\text { binded to apply the agreed } \\
\text { law. In regards to terms and } \\
\text { conditions for foreign } \\
\text { immigrants, freedom of }\end{array}$ \\
\hline
\end{tabular}

Page 224 


\begin{tabular}{|c|c|c|}
\hline & & $\begin{array}{l}\text { movement in Singapore will } \\
\text { be affected. Singapore, other } \\
\text { than to consider safety factor, } \\
\text { is obligated to protect } \\
\text { domestic workers and } \\
\text { entrepreneurs. }\end{array}$ \\
\hline & & $\begin{array}{l}\text { From the sovereignity's point } \\
\text { of view, ratification will open } \\
\text { opportunities for outside } \\
\text { parties (ASEAN, UN) to } \\
\text { control the application of } \\
\text { regulations regarding domestic } \\
\text { issues and internal laws. }\end{array}$ \\
\hline \multirow{3}{*}{3} & $\begin{array}{l}\text { Migrant } \\
\text { Worker } \\
\text { and } \\
\text { Family }\end{array}$ & $\begin{array}{l}\text { Rejecting, because the effect } \\
\text { will be the increase of } \\
\text { government expenditure as } \\
\text { well as effects to education } \\
\text { and health access and other } \\
\text { accesses. }\end{array}$ \\
\hline & $\begin{array}{l}\text { Protectio } \\
\mathrm{n} \text { for } \\
\text { Undocu } \\
\text { mented } \\
\text { Migrant }\end{array}$ & $\begin{array}{l}\text { Protection is specifically } \\
\text { rejected because it is already } \\
\text { covered in labour regulation } \\
\text { with focus to skilled and } \\
\text { certified migrant workers. } \\
\text { National security concerns, } \\
\text { such as migrant and illegal } \\
\text { drug distribution and threat of } \\
\text { terrorism, are also considered. }\end{array}$ \\
\hline & $\begin{array}{l}\text { Develop } \\
\text { ment vs } \\
\text { Human } \\
\text { Right } \\
\text { Approac } \\
\text { h }\end{array}$ & $\begin{array}{l}\text { Economy interest (efficiency, } \\
\text { growth) is still a main priority. } \\
\text { Migrants are considered to be } \\
\text { human capital. } \\
\text { Trade Union Act - migrant } \\
\text { workers must obtain permit to } \\
\text { be involved with the Labour } \\
\text { Union. National Trade Union } \\
\text { Congress has a close } \\
\text { connection with the incumbent } \\
\text { party, which is the People's } \\
\text { Action Party (PAP), and the } \\
\text { Singapore's political system. } \\
\text { (https://www.hrw.org/news/20 } \\
\text { 11/05/04/singapore). }\end{array}$ \\
\hline
\end{tabular}

Source: vary.

Malaysia's Rejection Rationale to Issues in ASEAN Instrument on the Protection and Promotion of the Rights of Migrant Workers 2017

\begin{tabular}{|l|l|c|}
\hline $\begin{array}{l}\mathrm{N} \\
\mathrm{o}\end{array}$ & Issue & Malaysia \\
\hline 1 & The & Rejecting, because the \\
\hline
\end{tabular}

Nature of Instrument will clash with the the Malaysia's Worker Act.

Instrume Worker Act has offered nt adequate protections needed (legally for migrant workers.

binding) Malaysia government places domestic household workers sector as informal sector which is not covered in employment regulations, however it is covered in immigration rules.

Per Employment Act 1955, domestic household worker is considered a slave without any rights. In regards to public policy, Malaysia government is explicitly not interested in protecting domestic household worker coming from migrant workers. In Employment Act Section 57 , it is firmly stated that rights of domestic household worker are only considered in regards to work termination. No other articles in that Act that relate to domestic household workers. This condition causes them to frequently receive discriminative treatments because their rights are nonexistent. This condition greatly differs if compared to migrant workers in other sector and from other countries.

(sekartrisakti.wordpress.com/ 2011/10/04/).

In 2002's Immigration Act, not much is mentioned about protection to domestic household workers. One of the regulation mentioned in the Act is about the singleentry policy, which states that domestic household migrant workers that comes to Malaysia must only be registered by one employer.

Malaysia relies in bilateral agreement, for example in 


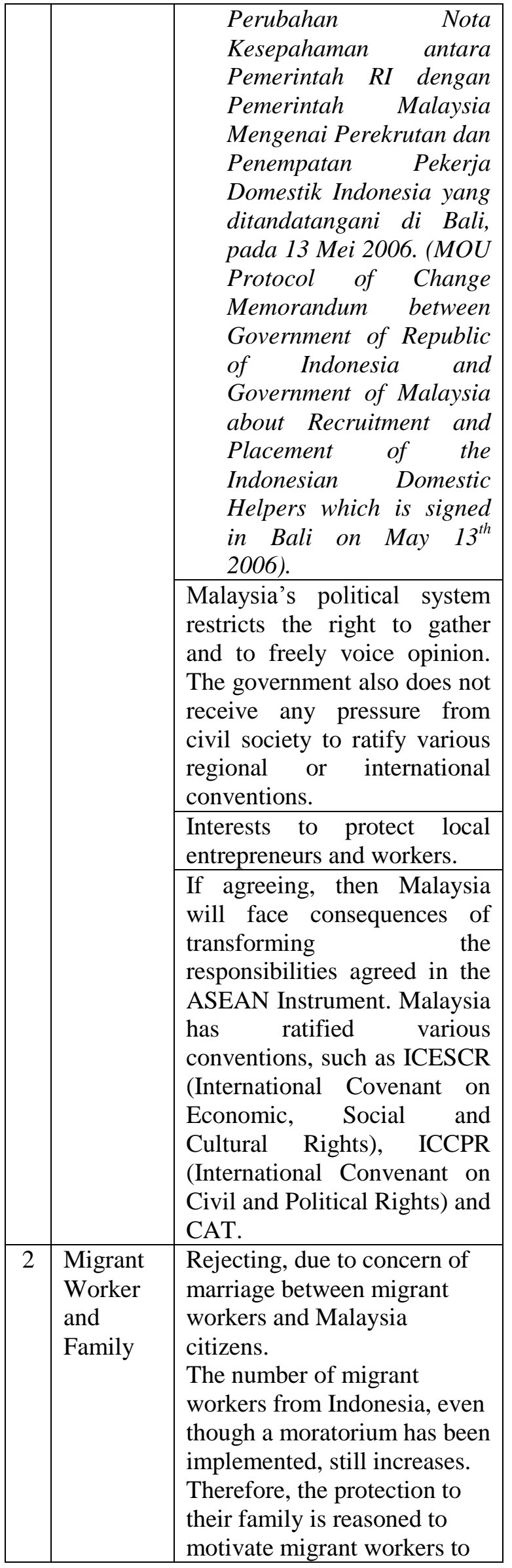

\begin{tabular}{|c|c|c|}
\hline & & $\begin{array}{l}\text { stay. } \\
\text { Family migration for } \\
\text { unskilled migrants is } \\
\text { prohibited. } \\
\text { Protection for undocumented } \\
\text { migrants in general is } \\
\text { unacceptable for both society } \\
\text { and media. }\end{array}$ \\
\hline 3 & $\begin{array}{l}\text { Undocu } \\
\text { mented } \\
\text { migrants }\end{array}$ & $\begin{array}{l}\text { Rejecting, however Malaysia } \\
\text { implements, limited } \\
\text { "whitening" policy to give } \\
\text { opportunities for migrant } \\
\text { workers to return back home. } \\
\text { For example, through the re- } \\
\text { hiring program with E-Kad } \\
\text { for migrant workers without } \\
\text { permits - in which } 197 \\
\text { Indonesia workers were } \\
\text { arrested (June 2017). } \\
\text { (http://kemlu.go.id/kualalump } \\
\text { ur/id/profil.aspx). }\end{array}$ \\
\hline 4 & $\begin{array}{l}\text { Develop } \\
\text { ment vs } \\
\text { Human } \\
\text { Right } \\
\text { Approac } \\
\text { h }\end{array}$ & $\begin{array}{l}\text { Worker recruitment agents in } \\
\text { Malaysia are highly } \\
\text { economical and political } \\
\text { instruments. Therefore, the } \\
\text { giving of license becomes a } \\
\text { "weapon" for government. } \\
\text { Many parties are benefitted } \\
\text { with the practice of } \\
\text { unprotected migrant workers. } \\
\text { That is why the number of } \\
\text { migrant worker victim is still } \\
\text { the highest in Malaysia - } \\
\text { because the nation does not } \\
\text { have the political will or the } \\
\text { capability to protect through } \\
\text { transparent regulations. }\end{array}$ \\
\hline
\end{tabular}

Source: vary

\section{Conclusion}

The existence of migrant workers in ASEAN for sending countries and recipient countries has important role in economics perspective. Migrant workers generate revenue for the nation they come from, maintain industrial's productivity, open employment, progress rural economy 
and sustain their family. However, due to its transboundary nature that involves different regulations from different nations, migrant workers are susceptible to violations against their rights, especially for blue collar migrant workers, informal sector and household. It is a state's duty to engage in coordinations and bilateral relationships to prevent migrant workers from experiencing various violations, especially violations against their human rights.

In the ASEAN context, ASEAN state members are responsible to work on protection for their workers' right as much as possible so that the existence of ASEAN is beneficial for its own society.

In the initiation case of ASEAN Instrument on the Protection and Promotion of the Rights of Migrant Workers - after a 10 year of negotiation process between 2007-2017 - ASEAN has yet to succeed in ratifying the Instrument that is legally binding for all ASEAN state members.

Various obstacles, especially from recipient countries, exist which cause the articles in the Instrument have yet to be agreed. At least four major issues arise, which are legally binding issue, migrant worker family issue, undocumented migrant issue, and approach to human rights issue. These obstacles show that
ASEAN state members have yet to focus on their "moral obligation" and still prioritize their economics and political interests.

As initiators, Indonesia and Philippines need to find ways which are acceptable for all parties, for instance through the National Law-Making that later can be standardized as National Policy to be one generalized ASEAN-level Customary Law. If so, then regional agreement can be reached where risks due to the emerging right violations against migrant workers can be shared (sharing risks) through specific ASEAN funding for all migrant workers that require protection. 
References

ASEAN Secretariat. 2007. ASEAN Documents Series 2006. Jakarta: ASEAN Secretariat.

ASEAN Agreement on the Protection and Promotion of the Rights of Migrant Workers. Working Draft developed by Filipina and Indonesia, presented in the Third Meeting of ACMW Drafting Team in Kuala Lumpur, December 2009.

ASEAN (Agreement) on the Promotion and Protection of the Rights of Migrant Workers. $2^{\text {nd }}$ Version of Zero draft as of 28 September 2012.

ASEAN (Agreement) on the Promotion and Protection of the Rights of Migrant Workers. Drafts as of 5 April 2012.

ASEAN (Agreement) on the Promotion and Protection of the Rights of Migrant Workers. $2^{\text {nd }}$ version of zero draft as of 4 October 2013 with Indonesia's Input on Article 28.

Bahan Masukan Pertemuan Menteri Luar Negeri RI-Laos Vientianne, Laos 809 Mei 2015

Working Draft ASEAN Consensus (Agreement) on the Promotion and Protection of the Rights of Migrant Workers. Working draft as of 20 February 2017.

Kementerian Luar Negeri RI. 2010. ASEAN Selayang Pandang Edisi ke-19.

Kementerian Luar Negeri RI. ASEAN 2025: Melangkah Maju Bersama.

Perempuan, Solidaritas. 2014. Situasi Kekerasan dan Pelanggaran Hak Buruh Migran Perempuan dan Keluarganya di Negara ASEAN.

The $4^{\text {th }}$ Meeting of the ASEAN Committee on the Implementation of the ASEAN Declaration on the Protection and Promotion of the Rights of Migrant Workers (ACMW) 11-12 April 2011, Jakarta, Indonesia

Working draft Instrument as of 17 December 2014. The $15^{\text {th }}$ Meeting of the ASEAN Committee on the Implementation of the ASEAN Declaration on the Protection and Promotion of the Rights of Migrant Workers-Instrument Drafting Team (ACMW-DT). Luang Prabang, Lao PDR: 17 December 2014

https://www.hrw.org/news/2011/05/04/sin gapore-un-rights-body-shouldpress-fundamental-freedoms 
https://www.theonlinecitizen.com/2016/01 /29/home-responds-to-singaporesclaim-of-happy-migrant-workersat-upr/

http://webcache.googleusercontent.com/se $\operatorname{arch?q=cache:http://www.respectf~}$ dwrights.com/wpcontent/uploads/2014/09/2012CEDAW-Singapore-ShadowReport.pdf

http://www.cetim.ch/legacy/fr/documents/ UNESCO-CMW-AsiePac1.pdf http://lib.ohchr.org/HRBodies/UPR/Docu ments/session11/SG/JS4_JointSub mission4-eng.pdf

https://www.hrw.org/report/2005/12/06/m aid-order/ending-abuses-againstmigrant-domestic-workerssingapore

https://www.hrw.org/reports/2005/singapo re1205/7.htm

https://www.hrw.org/reports/2005/singapo re1205/

http://www.cityu.edu.hk/searc/Resources/P aper/WP106_10_LKivinen.pdf http://www.aljazeera.com/indepth/opinion/ 2013/09/migrant-rights-time-fora-new-approach2013927133127159684.html http://www.ishr.ch/news/upr-singaporehigh-standard-living-offsetconcerns-over-migrants-andcorporal-punishment
http://www.trust.org/contentAsset/rawdata/19d35414-86d5-4dea-b5f0$487 \mathrm{dcdc} 8 \mathrm{f0d} 0 /$ file

file:///C:/Users/User.user-

PC/Downloads/Review\%20of\%20 labour\%20migration\%20policy $\% 2$ 0in\%20Malaysia.pdf

file:///C:/Users/User.user-

PC/Downloads/asa280032013en.p df

http://www.cetim.ch/legacy/fr/documents/ UNESCO-CMW-AsiePac1.pdf http://www.ialsnet.org/meetings/labour/pa pers/HassanGeorge-Malaysia.pdf http://www.newunionism.net/library/natio nal\%20data/Malaysia\%2012006.pdf

http://www.themalaymailonline.com/mala ysia/article/malaysia-will-notsign-un-convention-on-refugeessaysminister\#x8mw6RKkz6jA7bdD.9 7

https://www.hrw.org/sites/default/files/rep orts/indonesia0704full.pdf

file:///C:/Users/User.userPC/Downloads/ILO-Policy-Briefirregular-status.pdf http://thediplomat.com/2015/01/the-needfor-an-asean-treaty-on-migrantworkers/ http://www.suhakam.org.my/wpcontent/uploads/2013/12/SEANF- 
Paper-on-Migrant-Workers-

2010.pdf

http://aseanpeople.org/is-asean-closer-to-

legal-protection-of-the-rights-of-

migrant-workers/

https://www.fidh.org/IMG/pdf/MalaisieC

ONJ489eng.pdf

https://www.ncbi.nlm.nih.gov/pmc/articles

/PMC4308585/

https://humanrightsinasean.info/asean-

committee-migrant-

workers/about.html

http://library.fes.de/pdf-

files/bueros/philippinen/04519.pdf

https://publications.iom.int/system/files/pd

f/iom_background_paper_pressready

_afml.pdf

http://lup.lub.lu.se/luur/download?func=do

wnloadFile\&recordOId=2018830\&fi

leOId $=2027883$

http://www.alfea.org/img/OutsourcingCo

mpanies.pdf

http://www.bnp2tki.go.id/berita-

mainmenu-231/7548-pemerintah-

belum-cabut-moratorium-tki-plrt-ke-

malaysia.html

http://www.rri.co.id/madiun/post/berita/38

6336/daerah/indonesia_bahas_perlin

dungan_buruh_migran_di_ktt_asean.

html http://www.viva.co.id/berita/nasional/8609

55-perlindungan-pemerintah-untuk-

pahlawan-devisa-lemah

//sekartrisakti.wordpress.com/2011/1

0/04/kondisi-buruh-migran-

indonesia-diskursus-tentang-

perlindungan-dan-penegakan-hukum/ 